\title{
Bioremediation of textile effluent polluted soil using kenaf (Hibiscus cannabinus Linn.) and composted market waste
}

\author{
BADA, BS \\ Department of Environmental Management and Toxicology, \\ Federal University of Agriculture, Abeokuta, Ogun State, Nigeria, 110001. \\ Telephone number: +2348037250964 \\ E-mail:badabs@funaab.edu.ng
}

\begin{abstract}
This study determined the performance and heavy metals uptake of kenaf at different levels of compost application in textile effluent polluted soil. Polluted soil was collected from the vicinity of a textile company in Nigeria. Twelve-litre plastic pots were filled with $10 \mathrm{~kg}$ soil. Soil amendments applied were: 0 (control), $60 \mathrm{Kg} \mathrm{N} \mathrm{ha}^{-1}$ of N.P.K 20:10:10 (recommended rate), 40, 60, 80, and $100 \mathrm{Kg} \mathrm{N}^{-1}$ of Composted Market Waste (CMW). The pots were arranged in Completely Randomized Design and replicated three times. Growth parameters were taken. Plants were harvested 8 weeks after sowing and separated into leaves, stems and roots. Lead, Cadmium, Chromium and Zinc levels in plants and soil were determined using Atomic Absorption Spectrophotometer. Data were analysed using descriptive statistics and analysis of variance. CMW at $100 \mathrm{Kg} \mathrm{N} \mathrm{ha}^{-1}$ significantly $(\mathrm{p}<0.05$ ) enhanced the growth and yield of kenaf. Highest concentrations of heavy metals were observed in kenaf parts at 100 $\mathrm{Kg} \mathrm{N}$ ha ${ }^{-1}$ of CMW. Higher concentrations of Chromium $\left(0.15 \mathrm{mg} \mathrm{kg}^{-1}\right)$ Lead $\left(1.50 \mathrm{mg} \mathrm{kg}^{-1}\right)$ and Cadmium $\left(0.14 \mathrm{mg} \mathrm{kg}^{-1}\right)$ were observed in the root while higher concentration of Zinc (23.48 $\mathrm{mg} \mathrm{kg}^{-1}$ ) was observed in the leaf. (C) JASEM
\end{abstract}

http://dx.doi.org/10.4314/jasem.v19i4.26

\section{INTRODUCTION}

In Nigeria, industrial effluent is one of the sources of heavy metals in the environment. Textile industries produce large amount of polluted effluent which contain Chromium, Cadmium , Mangamese, Copper and Lead, Poornima et al., 2011). The effluents (both treated and untreated) are discharged into nearby land and water; and the heavy metals enter the human food chain through the fish, milk and meat of the animals fed on plants. $\mathrm{Zn}, \mathrm{Pb}, \mathrm{Cr}$ and $\mathrm{Cd}$ cause human disorder for instance lung cancer, chest pain, cough, vomiting, nausea, diarrhea, dry throat, headaches (Deepali and Gangwar, 2009). However, there is need to remove these pollutants from soil.

Remediation by excavation of polluted soil, putting fertile unpolluted soil on top of the polluted soil and using chelating agent to reduce bioavailability of heavy metals are very expensive (Gleseler, 1987). The use of plants to remove inorganic pollutants from soil (phytoremediation) has being in practice as an alternative to conventional methods.

Work has been done on the phytoremediation of $\mathrm{Cu}$ (Bada and Umunnakwe, 2011) using kenaf and inorganic fertilizer. Phytoremediation of textile effluent polluted soil using kenaf and composted market waste (organic fertilizer) as soil amendment will go a long way to solve the problem of solid waste management in Nigeria. This research was carried out to assess kenaf performance and its potential to uptake heavy metals in textile effluent polluted soil amended with composted market waste.

\section{MATERIALS AND METHODS}

Representative soil samples in the vicinity of a textile company (6 $6^{\circ} 34^{\prime} 19^{\prime \prime}$ N $3^{\circ} 29^{\prime} 9^{\prime \prime}$ E), Lagos state, Nigeria were collected to a depth of $0-15$ $\mathrm{cm}$ using soil auger. The soil physical and chemical properties were analysed before sowing kenaf.

Composted market waste was applied to $10 \mathrm{~kg}$ of the soil at the rate of $0,40,60,80$ and $100 \mathrm{~kg} \mathrm{~N}^{-}$ ${ }^{1}$. However, three weeks after sowing, recommended $60 \mathrm{~kg} \mathrm{~N} \mathrm{ha}^{-1}$ of N.P.K. 20:10:10 fertilizer (Ogunbodede and Adediran, 1996) was applied by side placement. All treatments were replicated three times. Kenaf were harvested at eight week after sowing by uprooting and separated into leaf, stem and root. Soil properties were also determined using the methods described in Chopra and Kanwar (2011). 
Obtained data were analysed using Analysis of variance while Least Significant Difference was used to separate means. Metal exclusion and metal accumulator were used to estimate kenaf heavy metals tolerance (Yangun et al., 2004). Ogundiran and Osibanjo (2004) stated that $\frac{\text { Shoot }}{\text { Root }}>1$ is metal accumulator, $\frac{\text { Shoot }}{\text { Root }}<1$ is metal excluder

\section{RESULTS AND DISCUSSION}

The effluent polluted soil was low in $\mathrm{N}\left(1.0 \mathrm{~g} \mathrm{~kg}^{-1}\right)$, $\mathrm{P}\left(1.7 \mathrm{mg} \mathrm{kg}^{-1}\right)$ and $\mathrm{K}\left(0.1 \mathrm{cmol} \mathrm{kg}{ }^{-1}\right)$ for crop production in Nigeria (FPDD, 1990). The soil also contained elevated concentrations of $\mathrm{Pb}(5.0 \mathrm{mg}$ $\left.\mathrm{kg}^{-1}\right), \mathrm{Cr}\left(5.5 \mathrm{mg} \mathrm{kg}^{-1}\right), \mathrm{Zn}\left(27.5 \mathrm{mg} \mathrm{kg}^{-1}\right)$ and $\mathrm{Cd}$ $\left(0.5 \mathrm{mg} \mathrm{kg}^{-1}\right)$ compared to $\mathrm{Pb}: 1.62 \mathrm{mg} \mathrm{kg}^{-1}$, Cr: $3.49 \mathrm{mg} \mathrm{kg}^{-1}$ and $\mathrm{Zn}: 6.06 \mathrm{mg} \mathrm{kg}^{-1}$ in effluent polluted soil (Poornima et al. 2011) and Cd: 0.018 $\mathrm{mg} \mathrm{kg}{ }^{-1}$ in untreated effluent (Deepali and Gangwar 2010).

Leaf, stem and root yields of kenaf increase with increase in the level of composted market waste (Table 1). The least significant $(\mathrm{p}<0.05)$ yield was observed at 0 (control). Higher leaf, stem and root yields were observed at $100 \mathrm{~kg} \mathrm{~N} \mathrm{ha}^{-1}$ of composted market waste. It is in agreement with previous finding of Bada and Fagbola (2014) that application of composted market waste increase the kenaf performance in the nutrient degraded soil.

The higher the level of composted market waste applied, the higher were the concentrations of heavy metals in the stem, leaf and root of kenaf (Table 2). Highest concentration of $\mathrm{Pb}$ was observed in the stem. This is not in agreement with the finding of Wozny et al. (1995) who reported that $\mathrm{Pb}$ is more accumulated in the roots of greening barley leaves. Highest concentration of $\mathrm{Cr}$ was observed in the root of kenaf. In contrary to this, Gafoori et al. (2011) reported highest concentration of chromium in the leaf. Kenaf had potential to accumulate $\mathrm{Pb}, \mathrm{Cr}, \mathrm{Cd}$ and $\mathrm{Zn}$ at every level of soil amendments (Table 3) ; shoot / root quotient greater than 1 (Ogundiran and Osibanjo 2008). Kenaf amendment with $100 \mathrm{~kg} \mathrm{~N} \mathrm{ha}^{-1}$ of composted market waste had the highest bioavailability index (Table 4). This might be due to the ability of composted market waste to enhance the growth of kenaf. For plant species to be suitable for phytoremediation, it must produce enough yields and accumulate high content of heavy metal (Chaney et al., 1997).

Concentrations of $\mathrm{Pb}, \mathrm{Cr}, \mathrm{Zn}$ and $\mathrm{Cd}$ reduced at all levels of composted market waste compared to the initial concentration in the effeluent polluted soil (Table 5). The least values of heavy metals observed at $100 \mathrm{~kg} \mathrm{~N} \mathrm{ha}^{-1}$ of composted market waste might be due to the ability of composted market waste to enhance the growth of kenaf in a nutrient degraded soil (Bada and Fagbola 2014).

Conclusion: Effluent polluted soil contained elevated concentrations of Lead, Chromium, Zinc and Cadmium. Application of composted market waste enhanced the growth, yield and heavy metals uptake of kenaf grown in textile effluent polluted soil.

Recommendations: Textile effluent should be treated before discharge into the environment. However, study need to be done on the phytotoxicity and phytoremediation potential of different varieties of kenaf

Table 1: Effect of soil amendments on the yield of kenaf parts

\begin{tabular}{|c|c|c|c|}
\hline $\begin{array}{l}\text { Soil amendment } \\
\left(\mathrm{kg} \mathrm{N} \mathrm{ha}^{-1}\right)\end{array}$ & Leaf $\left(\mathrm{g} \mathrm{pot}^{-1}\right)$ & Stem $\left(\mathrm{g} \mathrm{pot}^{-1}\right)$ & $\operatorname{Root}\left(\operatorname{g~pot}^{-1}\right)$ \\
\hline $\mathbf{0}$ & 0.07 & 0.19 & 0.09 \\
\hline CMW40 & 0.17 & 0.34 & 0.10 \\
\hline CMW60 & 0.22 & 0.43 & 0.11 \\
\hline CMW80 & 0.28 & 0.50 & 0.16 \\
\hline CMW100 & 0.37 & 0.64 & 0.21 \\
\hline NPK60 & 0.24 & 0.44 & 0.14 \\
\hline LSD & 0.17 & 0.20 & 0.12 \\
\hline
\end{tabular}


Table 2: Lead, Chromium, Zinc and Cadmium concentrations $\left(\mathrm{mg} \mathrm{kg}^{-1}\right)$ in kenaf parts.

\begin{tabular}{|c|c|c|c|c|c|c|c|c|c|c|c|c|}
\hline $\begin{array}{l}\text { Soil } \\
\text { amendment } \\
\left(\mathrm{kg} \mathrm{N} \mathrm{ha}^{-1}\right)\end{array}$ & & & Stem & & & & Root & & & & Leaf & \\
\hline & $\mathrm{Pb}$ & $\mathrm{Cr}$ & $\mathrm{Zn}$ & $\mathrm{Cd}$ & $\mathrm{Pb}$ & $\mathrm{Cr}$ & $\mathrm{Zn}$ & $\mathrm{Cd}$ & $\mathrm{Pb}$ & $\mathrm{Cr}$ & $\mathrm{Zn}$ & $\mathrm{Cd}$ \\
\hline $\mathbf{0}$ & 0.41 & 0.02 & 2.74 & 0.04 & 0.40 & 0.02 & 0.63 & 0.04 & 0.39 & 0.04 & 0.15 & 0.03 \\
\hline CMW40 & 1.00 & 0.07 & 6.75 & 0.10 & 1.00 & 0.08 & 1.73 & 0.10 & 1.00 & 0.10 & 5.58 & 0.10 \\
\hline CMW60 & 1.00 & 0.08 & 9.13 & 0.10 & 1.00 & 0.12 & 2.48 & 0.10 & 1.00 & 0.10 & 7.48 & 0.10 \\
\hline CMW80 & 1.00 & 0.12 & 9.88 & 0.10 & 1.17 & 0.13 & 2.85 & 0.13 & 1.00 & 0.12 & 11.30 & 0.12 \\
\hline CMW100 & 1.21 & 0.13 & 13.10 & 0.12 & 1.50 & 0.15 & 3.18 & 0.14 & 1.17 & 0.12 & 23.48 & 0.13 \\
\hline NPK60 & 1.00 & 0.10 & 9.52 & 0.10 & 1.17 & 0.12 & 2.72 & 0.12 & 1.00 & 0.12 & 8.92 & 0.12 \\
\hline LSD & 0.76 & 0.08 & 4.89 & 0.09 & 0.70 & 0.06 & 3.51 & 0.08 & 0.84 & 0.07 & 4.32 & 0.07 \\
\hline
\end{tabular}

CMW = Composted market waste

LSD $=$ Least Significant Difference

Table 3: Effect of soil amendments on shoot/root quotient of heavy metals in kenaf

\begin{tabular}{|c|c|c|c|c|c|c|c|c|c|c|c|c|}
\hline & & Shoot & & & & Root & & & & $\begin{array}{l}\text { Shoo } \\
\text { ot }\end{array}$ & & \\
\hline $\begin{array}{l}\text { Soil amendments } \\
\left(\mathrm{kg} \mathrm{N} \mathrm{ha}^{-1}\right)\end{array}$ & $\mathrm{Pb}$ & $\mathrm{Cr}$ & $\mathrm{Zn}$ & $\mathrm{Cd}$ & $\mathrm{Pb}$ & $\mathrm{Cr}$ & $\mathrm{Zn}$ & $\mathrm{Cd}$ & $\mathrm{Pb}$ & $\mathrm{Cr}$ & $\mathrm{Zn}$ & $\mathrm{Cd}$ \\
\hline 0 & 0.8 & 0.06 & 2.89 & 0.07 & 0.40 & 0.02 & 0.63 & 0.04 & 2.00 & 3.00 & 4.59 & 1.75 \\
\hline CMW40 & 2.0 & 0.17 & 12.33 & 0.20 & 1.00 & 0.08 & 1.73 & 0.10 & 2.00 & 2.13 & 7.13 & 2.00 \\
\hline CMW60 & 2.0 & 0.18 & 16.61 & 0.20 & 1.00 & 0.12 & 2.48 & 0.10 & 2.00 & 1.50 & 6.70 & 2.00 \\
\hline CMW80 & 2.0 & 0.24 & 21.18 & 0.22 & 1.17 & 0.13 & 2.85 & 0.13 & 1.71 & 1.85 & 7.43 & 1.69 \\
\hline CMW100 & 2.38 & 0.25 & 36.58 & 0.25 & 1.50 & 0.15 & 3.18 & 0.14 & 1.59 & 1.67 & 11.50 & 1.79 \\
\hline NPK60 & 2.0 & 0.22 & 18.44 & 0.22 & 1.17 & 0.12 & 2.72 & 0.12 & 1.71 & 1.83 & 6.78 & 1.83 \\
\hline
\end{tabular}

CMW = Composted market waste

Table 4: Effect of soil amendments on the bioavailability index of kenaf

\begin{tabular}{|c|c|c|c|c|c|c|c|c|}
\hline & & Absorption & & & & $\begin{array}{l}\text { Bioava } \\
\text { bility } \\
\text { index }\end{array}$ & & \\
\hline $\begin{array}{l}\text { Soil amendment } \\
\left(\mathrm{kg} \mathrm{N} \mathrm{ha}^{-1}\right.\end{array}$ & $\mathrm{Pb}$ & $\mathrm{Cr}$ & $\mathrm{Zn}$ & $\mathrm{Cd}$ & $\mathrm{Pb}$ & $\mathrm{Cr}$ & $\mathrm{Zn}$ & $\mathrm{Cd}$ \\
\hline 0 & 1.20 & 0.08 & 3.42 & 0.11 & 0.24 & 0.015 & 0.12 & 0.22 \\
\hline CMW40 & 3.00 & 0.25 & 14.06 & 0.30 & 0.60 & 0.045 & 0.51 & 0.60 \\
\hline CMW60 & 3.00 & 0.30 & 19.09 & 0.30 & 0.60 & 0.055 & 0.69 & 0.60 \\
\hline CMW80 & 3.17 & 0.37 & 24.03 & 0.35 & 0.63 & 0.067 & 0.87 & 0.70 \\
\hline CMW100 & 3.88 & 0.40 & 39.76 & 0.39 & 0.78 & 0.073 & 1.45 & 0.78 \\
\hline NPK60 & 3.17 & 0.34 & 21.16 & 0.34 & 0.63 & 0.062 & 0.77 & 0.68 \\
\hline BS & 5.00 & 5.50 & 27.50 & 0.50 & & & & \\
\hline
\end{tabular}

CMW = Composted market waste

$\mathrm{BS}=$ Before Sowing

Table 5: Chromium, Lead, Zinc and cadmium concentrations $\left(\mathrm{mg} \mathrm{kg}^{-1}\right)$ in soil after harvesting

\begin{tabular}{lllll}
\hline $\begin{array}{c}\text { Soil amendment } \\
\left(\mathrm{kg} \mathrm{N} \mathrm{ha}^{-1}\right)\end{array}$ & Chromium & Lead & Zinc & Cadmium \\
\hline 0 & 4.61 & 3.10 & 17.50 & 0.35 \\
CMW40 & 0.12 & 1.00 & 16.88 & 0.10 \\
CMW60 & 0.10 & 1.00 & 13.10 & 0.06 \\
CMW80 & 0.10 & 1.00 & 11.43 & 0.04 \\
CMW100 & 0.10 & 1.00 & 8.63 & 0.03 \\
NPK60 & 0.10 & 1.00 & 12.92 & 0.06 \\
LSD & 0.08 & 0.84 & 8.99 & 0.02 \\
BS & 5.50 & 5.00 & 27.50 & 0.50 \\
\hline
\end{tabular}

CMW = Composted market waste

LSD = Least Significant Difference

$\mathrm{BS}=$ Before Sowing 


\section{REFERENCE}

Bada, B S; Fagbola, A (2014). Effects of Arbuscular Mycorrhiza and Composted Market Waste on the Performance of Tiannug 1 Variety of Kenaf (Hibiscus cannabinus Linn.). Int J Biol Chem Sci 8(3): $1151-1164$.

Bada, B S; Umunnakwe, C F (2011). Phytoremediation potential of kenaf (Hibiscus cannabinus Linn.) under different soil $\mathrm{pH}$ and copper concentrations. J Sci Res 10(2): 160 166.

Chaney, R L, Malik, M, Li, Y M, Brown, S L, Brewer, G P; Baker, A J M (1997).

Phytoremediation of soil metal. Curr Opin Biotech 18: $279-284$.

Chopra, S L; Kanwar, J S (2011). Analytical Agricultural Chemistry. Kalyani publishers, New Delhi. p. $152-195$.

Deepali, B D; Gangwar, K K (2009). Assessment of heavy metals status in effluent

of a textile industry at hardwar. J Environ Biol Sci 23(1): $29-31$.

De Voss, C H R, Schat, H, De Waal, M A M, Voojs, R; Ernst WHO (1991). Increased resistance to copper-induced damage of the root cell plasmalemma in copper-tolerant Silene cucubalus. Physiol Plant-run 82: 523 - 528.

FPDD (Fertilizer Procurement and Distribution Division) (1990). Literature Review on soil fertility investigations in Nigeria. Fed. Min. of Agric. Water Resour. Rural Dev. Food Chem 78: 63-68.
Gleseler, (1987). Contaminated land in the EC: Report of contract No. 85-B6632-11-006-11-N (EC), system GMBH, Fredrichshafen.

Ogunbodede, B A; Adediran, J A (1996). Effect of nitrogen application on two new mutants of kenaf (Hibiscus cannabinus L.) on an Alfisols in the rainforest zone of Nigeria. Paper presented at International Atomic Energy Agency (IAEA) Workshop on use of nuclear techniques to develop improved crop varieties, Bamako, Mali. p. 10

Ogundiran, M B; Osibanjo, O (2008). Heavy metal concentrations in soils and accumulation in plants growing in a deserted slag dumpsite in Nigeria, Afr J of Biotech 7(17): 3053-3060.

Poornima K, Vasudevan K, Venkatshwarlu M. 2011. Evaluation of heavy metals in textile effluents in relation to soil and pond water. Elec $\mathrm{J}$ of Environ Sci. 4: 79- 84 .

Rotkittikhun R, Kruatrachue M, Chaiyarat R, Ngernsansaruay C, Pokethitiyook P,

Paijitprapapora A, Baker AJM. 2006. Uptake and accumulation of lead by plants from the Bo Ngam lead mine area in Thailand. Environ Pollu 144: 681-688.

Wozny A, Schneider J, Gwozdz EA. 1995. The effects of lead and kinetin on greening barley leaves. Biol Plant 37: 541-552.

Yanqun Z, Yuan L, Schvartz C, Langlade L, Fan L. 2004. Accumulation of $\mathrm{Pb}, \mathrm{Cd}, \mathrm{Cu}$, and $\mathrm{Zn}$ in Plants and hyperaccumulator choice in Landing lead-zinc mine area, China, Environ Int 30: 567 576. 